\title{
Contribution of Community Forestry in the Local livelihood and Resource Management in Touk Kaki, Cambodia
}

\author{
Mang Tukla ${ }^{1}$, Xue Yongji1
}

\begin{abstract}
${ }^{1}$ School of Economic and Management, Beijing Forestry University, No (35) Qinghua East Road, Haidian District, Beijing, P.R. China, Post code-100084
\end{abstract}

\begin{abstract}
Livelihoods of community are largely based on the forest; they could be expected to be strongly committed to preserving the forest and its non-timber forest products (NTFP) resources while at the same time using them for their daily livelihood. Local benefits are limited to the uses of forest resources. The incomes achieved are barely enough to support and improve the livelihoods while many study have revealed that resource are being declined due to over exploitation. The objective of study is to evaluate the process of community forestry and how community forestry contributes to maintain sustainable resource and to the local livelihood wellbeing. 125 households were selected randomly for the questionnaire survey in Toul Kaki commune. Logistic regression results have revealed that most of local household depend mostly on fishing in mangrove forest. Logistic regression also shown crop plantation and rice farming were also important after fishing activities to the share of better off of local household. In conclusion, as the community forestry in Toul Kaki is more rely on rice farming and fishery resource, this community forestry has a great different from other community forestry. Fishery resources are the main contribution from forest as the main NTFPs in the community. However, the community forestry has been successfully implemented since more household are betteroff after 5 years of establishment of CF. Forestry commune council was the most active local institute helping and support local community for their livelihood activities with the help of local NGOs that were doing relevant activities.
\end{abstract}

Keywords: Cambodia, livelihood, effectiveness, multiple regression, NTFPs, local institute, mangrove forest, and fishery resources

\section{INTRODUCTION}

GMO has introduced to the world to make sure food security is compromised. Forestry also is important resource that needs more technology and management make the need of future is compromised too. More than 2 billion people is expected by 2025 $(\mathrm{UNPF})^{1}$, forest security should be maintained for upcoming over population growth to fulfill the need because not only food but also forest resource that are need for long term welfare living. To make sustainable forest exploitation, we may focus on forest plantation like fast growing tree species. In addition to forest plantation, remaining forest is even more important to manage as they are multifunctional forest with rich of biodiversity and main sources for local people food and their ethnicity.

\begin{abstract}
There are varieties values of forest ecosystem (figure 1). The question is how can use this resource sustainably consume? Among these management methodology, community forestry is one of the best practice to protect remaining forest while it is possible to harvest NTFPs and timber to maintain and improve people living standards. This has been practicing and implementing very successfully in many countries like Nepal, India, and some African countries. Yet, community forestry was first introduced to Cambodia in the 1990s and has been spread all over the country until now (Sokh et al. $2000)^{2}$. Promoting the development of community forestry can improve livelihoods of communities in forest areas and also encourage the conservation of forests and their precious natural resources. However,
\end{abstract}

\footnotetext{
${ }^{2}$ Sokh et al., 2000, Community Forestry in Northern Cambodia, Kyushu University, Fukuoka 812-0053
}

${ }^{1}$ United Nation of Population Fund

This article is published under the terms of the Creative Commons Attribution License 4.0 Author(s) retain the copyright of this article. Publication rights with Alkhaer Publications.

Published at: http://www.ijsciences.com/pub/issue/2017-05/

DOI: 10.18483/ijSci.1266; Online ISSN: 2305-3925; Print ISSN: 2410-4477 
depletion of both timber and non-timber uses in

management sector.

Cambodia became a serious issue alerting forest

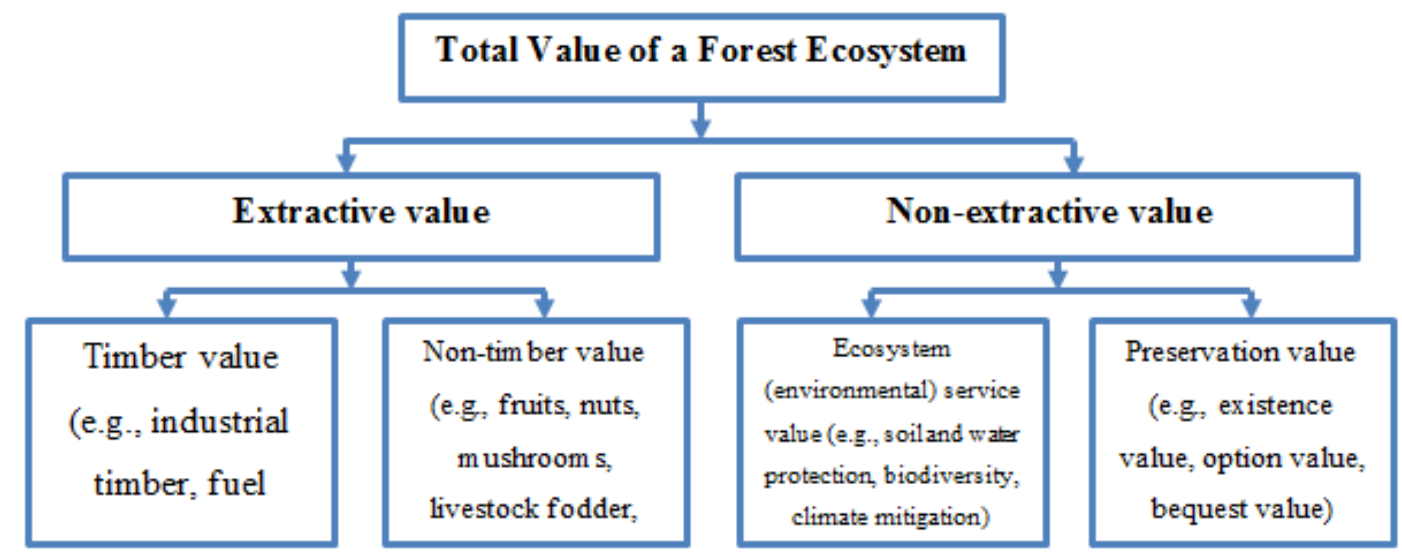

Figure 1: Total value of a forest ecosystem, adopted from Zhang and Pearse (2012)

Cambodia has total population of 14 million which most people are living under the poverty line (NIS, $2013)^{3}$. These people are depending mostly on forest ecosystem for food, shelter, culture and other daily uses. Production of forest has been one of the most important roles playing in country economic growth and development for decades. About $85 \%$ of Cambodia people depend on agriculture, wood, and NTFP for daily economic subsistence (FAO, 1998) ${ }^{4}$. More than $50 \%$ of them are living with direct economic benefit from forest in which forest resource is the main livelihood contribution (FA, 2014) $)^{5}$. Over the year of political development, forest ecosystem in somewhat have undergone different type of disturbance for both domestic and commercial purposes. Therefore, forest resource depletion has become a serious problem in the whole country leading high attention from local and International NGOs and RGC $^{6}$ who try to provide fund, develop and improve their management through community forestry ${ }^{7}$.

\footnotetext{
${ }^{3}$ National Institute of Statistics, Ministry of Planning Socio-Economic Survey (2013)

4 Food and Agriculture Organization, 1998. More than $50 \%$ of Cambodian population rely mostly on forest timber and wood for housing construction and fuel wood. NTFPs as their daily food mushroom, vegetable, seed, rattan, bamboo and vine.

5 Forestry Administration, (2014), 2.2 million households (71 \% of the total population), mostly living in upland watershed areas and in the Tonle Sap region rely directly on forest for their livelihoods.

${ }^{6}$ Royal Government of Cambodia

7 RECOFTC, 2011, Community Forestry covered 400, 000 ha involved by 60, 000 households from 450 villages.
}

\subsection{Problem Statement}

However, economic status of local villager in community forestry is still under questioning and investigating by RGC and NGOs in term of sustainable forest management. Socioeconomic status before and after establishment of Community Forestry have not been clarified whether they are effective in term of economic benefits. According to (Chan, 2005), the income level before and after establishment of community forestry is not high sensitive changed (Chan D, 2005) ${ }^{8}$ which mean current practice of community forestry management should be changed or improved. Moreover, reliable baseline of socioeconomic status has never been recorded making it difficult when preparing management plan and reallocation of resources for long term implementation of Community Forestry. For long term use of these resources, assessment socioeconomic status is needed to be evaluated to inspect the community forestry development process. Through the assessments, obstacles between community and forest management institute will be found, therefor solution and recommendation will be made to improve or to maintain in order to promote sustainable forest management. Moreover, economic assessment will be crucial sources for donor like local and international NGOs and government to investigate their fund and management effectiveness in term of economic well-being.

\footnotetext{
8 Chan. D. 2005, The Impact of a Community Forestry Project in a Northwest Watershed of Cambodia, Studies and Experiences from Asian, pg. 249-250. AIT, Bangkok, 2005
} 


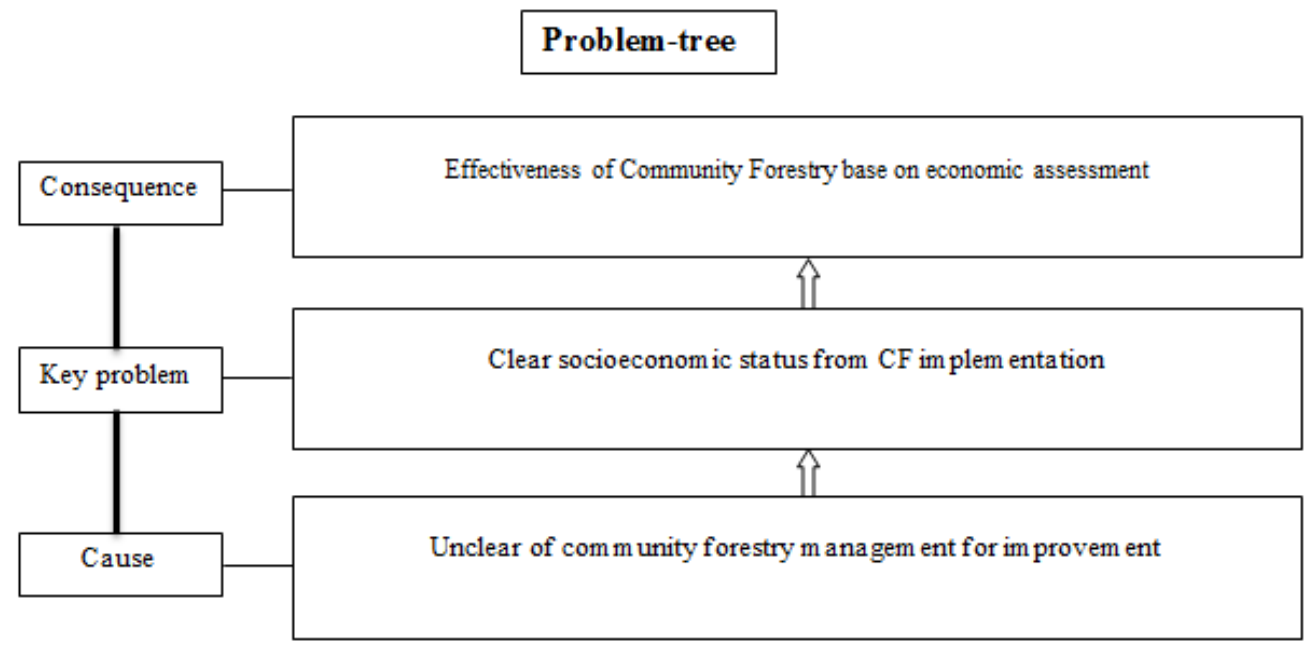

Figure 2: Problem tree appearing in community forestry

\section{OBJECTIVES}

After nearly three decades of strife in the latter half of the 20th century, Cambodia still remains one of the poorest countries in the world as a result of poverty remains serious problem throughout the country. Cambodian households can earn between USD167 and USD424/household/year from NTFPs ${ }^{9}$, and $30-42 \%$ of their incomes come from forests annually (K.K. Hansen et al., 2006)10. About 1.4 million people living within $5 \mathrm{~km}$ of evergreen and semi-evergreen. From forest, these people do resin collection 11, hunting, fishing and other NTFPs that account for almost half of household income as an example of Modulkiri province ${ }^{12}$.

As forest resources including timber and NTFPs in somewhat already severely degraded or tend to be degraded in Cambodia, it is essential that local communities are actively involved with forest management, as they are closest to the forest and are knowledgeable about it. As such, they can routinely monitor the condition of the forest and its resources.

9 This is not included people living in city and provincial area

${ }^{10}$ K.K. Hansen et al., 2006, Natural Forest Benefits and Economic Analysis of Natural Forest Conversion in Cambodia, Cambodia Development Resource Institute

${ }^{11}$ From resin collection alone, a household can earn from USD \$100-340 depending on number of tree owned by the tapper with the labors day of 45-55 days per year (Unknown author, 2010)

12 Loss of the household income causing from logging and clearance for economic land concession that happen in Peam Krasoab, Cambodia.
Livelihoods of community are largely based on the forest; they could be expected to be strongly committed to preserving the forest and its NTFP resources. From this view, we are sure that community forestry can bring promising results in ecological, economic, and social front that lead to sustainability. On the other hand, degraded forests and high commercial demand with fast population growth make utilization of forest products unsustain $^{13}$. Therefore, socioeconomic of local villager living the community needs to be acknowledged for improvement and monitoring in order to make sure that the community management is worth the run. Otherwise, NGOs fund and other financial support will be waste. From this research, livelihood activities in the community forestry are the criteria that will be used to evaluate the community forestry and how these activities have been performed and improved to make local families better off after the establishment community forestry.

\footnotetext{
13 Degraded forests and high commercial demand caused by agro-industry, mining, encroachment, land grabbing for investment and illegal logging leading to lose of forest area from $57 \%$ to 53 in last two decades (Glen M. (CIFOR) \& Manuel B. (CIFOR \& CIRAD), 2014.
} 


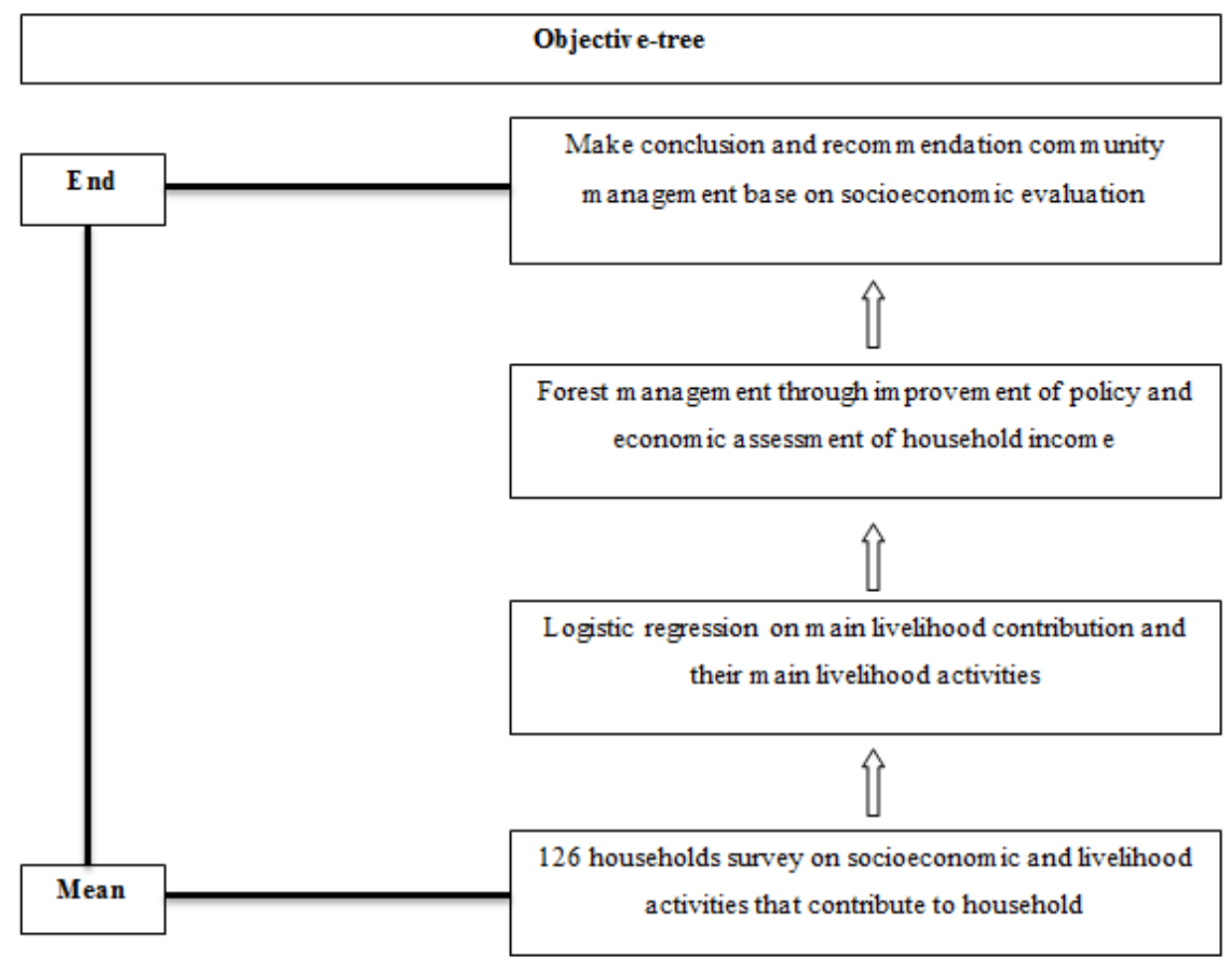

Figure 3: Objective tree of proposed research

These proposed objectives attempted to solve the problem that appears in the Cambodian community forestry management unit to fulfill the long-term goals of sustainable forest management base community forestry. In addition to NTFPs collection, economic survey will be made to investigate other factors that daily contribute to community subsistence in including fishing, crop farming, livestock and rice farming etc.....

Economic assessment is an important indicator to evaluate the process and effectiveness of the community forestry. Our overall objective is to identify effectiveness of community forestry by using two indicators:

(1) Constitutional factor: refer to intervention and communication between local villager local institute and NGO that have been working together in the community forestry with the reflection from the local villager on their current practice. This will help government, policy maker and NGOs to develop and improve their project management on their institutional level.

(2) Socioeconomic status which is refers to contribution of community forestry to local livelihood: main occupation and role of community forestry in the community livelihood. From economic assessment surveys, we can investigate the main contribution of community forestry on the status of economic prosperity from local villager perception before and after the establishment of community forestry.

\subsection{Research Objective Questions}

This research project is important for villagers living in the area for several reasons by answering the questions below;

(1) From community forestry, how community has involved within the research site, to change their livelihood activities for securing their livelihoods?

(2) What are the contributions of community forestry to the whole community indicated by villager perception on their economic status change?

(3) What should government improve management plan on these limit resources to make community forestry management more effective?

These questions will be answered by economic assessment: to analyze the economic status of community through questionnaire to find out their main occupation from contribution of forest ecosystem to their daily living. Then, evaluate the contribution of community forestry to whole 
community from various types of livelihood activities. Finally, to investigate the cooperation between government, NGOs and local institute and challenge in the community forestry on their current practice that essential for long-term management monitoring and management plan for improvement.

\subsection{Motivation of the Study}

Forest management in Cambodia has been a challenging task for the Cambodian government from the 1950 s to the present. According to the remaining available records, forest management systems have been evolved from solely timber benefit management to timber, non-timber forest products (NTFPs), and environmentally friendly management. Past management, moreover, was focused mainly on national economics. However, for the last ten years or so forest management has encompassed timber production, the environment, tourism recreation, and benefit sharing among national and local economies.

For the latter, the RGC has been confronted with a challenging task due to fast emerging demands for timber and NTFPs while human and financial resources are changing their needs. It is difficult to make generalizations about its effectiveness (Frances H. L., et al, 2014). This is perfectly true because there are many factors indicating the effectiveness of community forestry.

However, from this study, two indications will be identified about effectiveness of Touk Kaki community forestry. Socioeconomic status that mostly refers to contribution of CF to the local each household economic and daily subsistence and quality of forest regarding to the structure and its diversity richness. These two indicators are considerably important indicator of success as it has ecological and social significance.

Community Forestry objectives are to accelerate high potential for economic gain but it hard to achieve in term of technical, management, policy, planning, social and institutional factors. In somewhat, the Community Forestry management appear to be very successful in economic but have negative impact on environment. From these assessment objectives, we will be able to identify viability of Community Forestry whether it has a capacity to meet or not the defined objectives.

Community Forestry initiatives are still very much driven by international donor organizations, international and national NGOs, but recently communities are becoming more proactive, using direct approaches to address local problems.
However, central level commitment expressed in policy documents has fallen short in practice (lack law enforcement), but commitments set from provincial authorities/governors remains crucial to the success of these initiatives (Seng H., Iida Sh., 2002). Community Forestry has to take the needs of the resource users into consideration; therefore applied approaches/tools have to be flexible, realistic, practical, simple, independent and participatory.

A recommendation had made (Fichtenau, et al., 2002) that a number of open questions and a clear need for further in-depth knowledge on mainly socioeconomic and technical aspects ${ }^{14}$. Therefore, the assessment of resources and socioeconomic status of Community Forestry from this is very important baseline information for the future development. Moreover, the research finding will provides quantitative and qualitative data on presently practice of Community Forestry in Touk Kaki commune.

There has been no assessment of the impact of Community Forestry on the socio-economic situation of participating households (Sunderlin 2006). That reported, because only degraded forest areas with little timber value have been allocated for Community Forestry, local benefits are limited to collection of non-timber forest products (NTFP): the incomes achieved are barely enough to support let alone improve the livelihoods of local forestdependent people. In contrast, state-owned forests have high economic value, i.e. rare tree species, highvalue timber, rich biodiversity and more NTFP, and generate more forest income than private and community-owned forests both per household and per hectare (Jagger et al. 2014). An assessment of the detailed contribution of forest goods and services at the local level is urgently needed so that appropriate intervention and development policies could be introduced.

Community Forestry in Cambodia requires more policy-making attention and more financial and technical resources if it is to make any significant contribution to biodiversity conservation and poverty alleviation in Cambodia (Lopez, T. Td., 2000) ${ }^{15}$. Community Forestry agreements in Cambodia are

\footnotetext{
14 Fichtenau, et al., 2002, An assessment of ongoing Community Forestry Initiatives in Cambodia, Department of Forestry and Wildlife, Phnom Penh, Cambodia

15 De Lopez T. T., 2000, Resource Degradation, Property Rights, Social Capital and Community

Forestry in Cambodia, Cambodian Research Centre for Development (CRCD), Kingdom of Cambodia.
} 
limited to a 15-year renewable term (Yeang, D. $2012)^{16}$, it is important for government to consider the socioeconomic status before extend further practice of CF. Some degraded areas that have been improved under community management, however, may be reallocated to more powerful individuals or groups by the government (Fisher 2013). Therefore, this study will collect all related data about land resource assessment, food security status, general livelihood reflection and institutions facilitated their livelihood. Moreover, to improve economic benefit from these Community Forestry, assessment of economic situation of people in the community need to be analyzed to make some better change for effective economic benefits.

This research is important for villagers living in Community Forestry for several reasons. Initially, it will provide very useful local knowledge and information on management action to Community Forestry management sector which reflect from economic status and economic benefits flow direct and indirect from their forest ecosystem (from objective conjoint response of income). This information is needed by the Community Forestry department to formulate its national management plan program to reallocate or to extend the use right base on 15 years' CF renewal plan. Secondly, building the community's capacity and fostering resilience to depletion of resources will contribute to the overall sustainable management of natural resources in Touk Kaki community forestry. Enhanced livelihoods and skills gained from this action research project (meeting, discussion, and questionnaire in methodology part) will enable the communities to work together to find innovative ways to reduce pressures on natural resources and to better cope with food security problem. Third, capacity building for the research team will be of great benefit for the RGC especially department of Community Forestry, FA, which is in dire need of qualified research and policy personnel.

\section{METHODOLOGY}

\subsection{Study Area and Background}

Touk Kaki is a long established rice-farming commune, near national route \# 48, surrounded by both mangrove and upland forests. Its terrain is considered as a highland site, where there are plenty of mountainous forests and water systems that connect to the coastal area (figure 3.1). Most

16 Yeang, D. (2012). Community Tenure Rights and REDD+: A Review of the Oddar Meanchey Community Forestry REDD+ Project in Cambodia. Pg. 269. ASEAS - Austrian Journal of South-East Asian Studies, 5(2), 263-274. villagers earn their livelihood through rice farming and upland agriculture; the other activities are fishing, cutting mangrovewood, making charcoal or selling goods. For farmers, fishing practices supplement the family income or are undertaken for subsistence use (PMMR, Phase 1 Final Report, p 22). 
Table 1: Demographic informtion about people living in Toul Kaki commune, commune cheif interview January 2017.

\begin{tabular}{|l|l|l|l|l|l|l|l|l|}
\hline \multirow{2}{*}{$\mathbf{N}^{\mathbf{O}}$} & \multirow{2}{*}{ Village } & \multicolumn{3}{|l|}{ Number of Households } & \multicolumn{2}{l|}{ Number of People } \\
\cline { 3 - 10 } & & Total & Permanent & Temporary & Total & Female & \multicolumn{2}{l|}{ Permanent } \\
\hline 1 & 2 & 3 & 4 & 5 & 6 & 7 & 8 & 9 \\
\hline 1 & $\begin{array}{l}\text { Toul Kaki } \\
\text { Kraom }\end{array}$ & 38 & 38 & - & 170 & 76 & 170 & 76 \\
\hline 2 & $\begin{array}{l}\text { Toul Kaki } \\
\text { Leu }\end{array}$ & 59 & 54 & 5 & 271 & 137 & 255 & 131 \\
\hline 3 & Tachat & 100 & 100 & - & 482 & 251 & 482 & 251 \\
\hline 4 & Koh Chak & 44 & 44 & - & 211 & 117 & 211 & 117 \\
\hline Total & & 241 & 236 & 5 & 1134 & 581 & 1118 & 575 \\
\hline
\end{tabular}

Toul Kaki commune contained four villages including Toul KaKi Kraom, Toul Kaki Leu, Ta Chat and Koh Chak village. This commune had 241 families that equal 1134 people in which 581 people as female around $51 \%$ of the total population (Kim Sokhem, chief of commune, 2011).

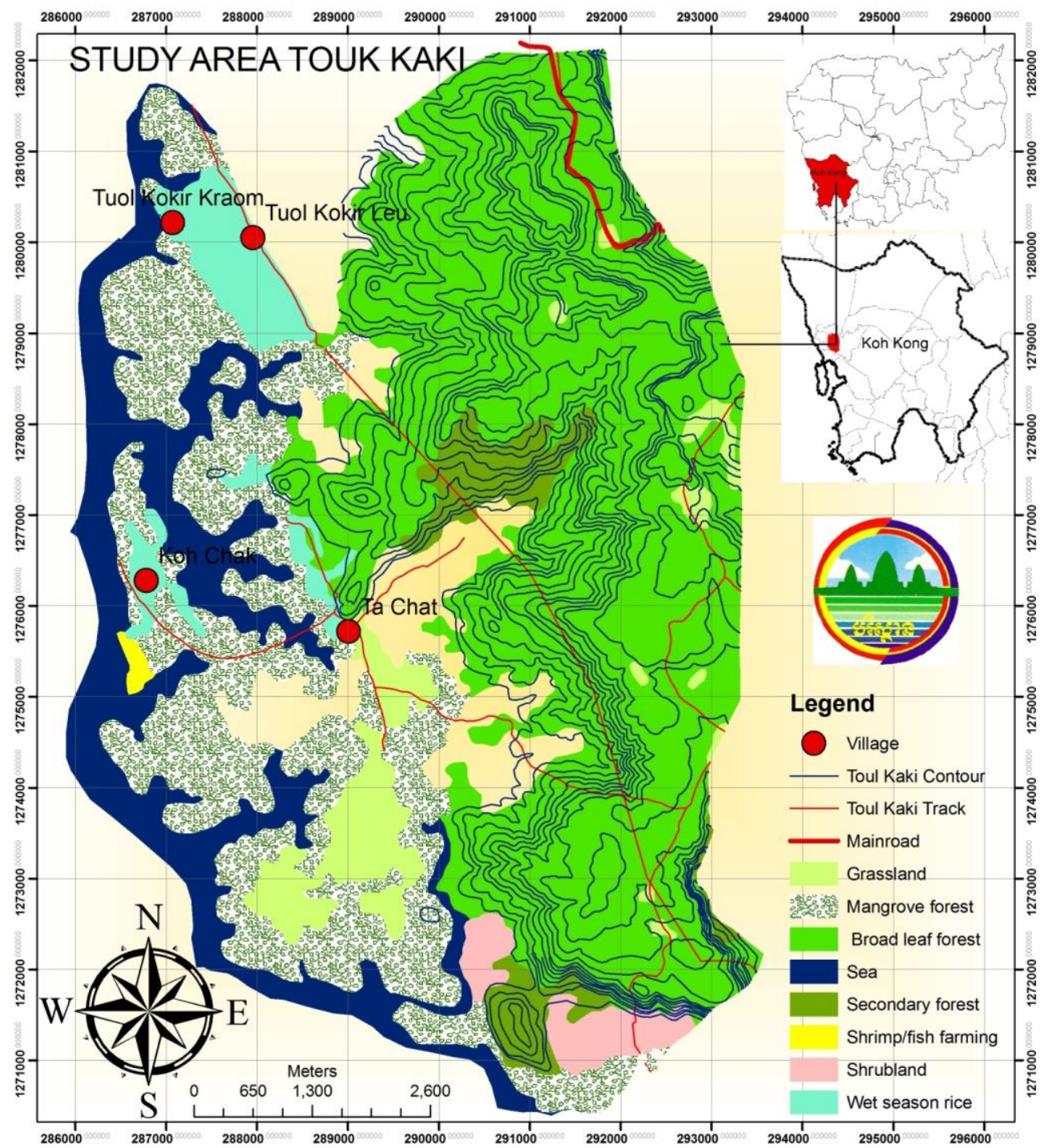

Figure 4: 3.1: Research area Touk Kaki, Koh Kong province, Cambodia 


\subsection{Data Collection}

This research was based on primary data (field data collection) and secondary data from the Learning Institute (LI), Forestry Administration Cambodia, Food and Agriculture Organization.

Primary data: Field data collection was divided into 4 parts as the following:

a. General information about Touk Kaki community forestry will be obtained through key informants including chief of the commune, government officials from Provincial Department of Environment and elder local people.

b. Focus group discussion will be made with participants who are the key informants: village chiefs, elder villagers, active farmers (villager), and other stakeholders. This focus group is believed to be more aware of the village situation than others. The discussion aimed to record occupation (income sources), livelihood levels and food security status, challenges in their livelihoods and other interests from community.

c. Participatory mapping of the study site: outstanding local residents will be selected who have a good knowledge of the villages, daily activities throughout the Community Forestry area. The survey team will allow them to draw the village map, the areas where they go to collect NTFPs and farming, their access routes to travel in the village, forest area and their fresh water sources (streams and ponds in the forest). This participatory mapping will made to see where their resources (agricultural products, NTFPs including fresh water, fish and forests) and how these resources change based on their practical opinion and how it challenges them.

d. Household survey with Questionnaires will be made among 126 families out of 246 families in the community. Those 126 families will be randomly selected, and the survey will be taken between $30-$ 45 minutes per household to complete. The questionnaires will relate to general information of respondents, livelihood activities (occupation), perception of Community Forestry management (both local and governmental management), forest resource assessment, land resource assessment, food security status, general livelihood reflection and institutions facilitated their livelihood.

\subsection{Data Analysis}

\subsubsection{Community Forestry Dependency}

Generally, villager living in forest areas depend on forest and forest resource for their daily livelihood for their food, floss, fuel wood, fodder and grazing. Forest resources bring local people in the community daily subsistence. The subsistence can be included as food, housing, fuelwood, water, wildlife, and other noncash value. Some of these sources that people get from forest resources will be evaluated into cash value. Multiple regression analysis will be used to test the relation between income and their routine activities spending in forest.

In Cambodia, forest-dependent communities collect NTFPs from different types of forest such as production forest, protected forest and community forestrys in order to support their livelihood, income and daily subsistence (Prom, et al, 2010). Logistic regression for data analysis is as follow;

$$
\begin{aligned}
P(\text { betterof } \mid x)= & \alpha+\beta_{1} \text { Lvact } 1+\beta_{2} \text { Lvact } 2 \\
& +\beta_{3} \text { Lvact } 3+\beta_{4} \text { Lvact } 4 \ldots \ldots+\mu
\end{aligned}
$$

$P($ betteroff $)=$ Probability of people get better off after establishment of $\mathrm{CF}$

$\beta_{1 \text { Livact } 1}=$ Slop of livelihood activity 1 contribute to community livelihood

$\beta_{2 \text { Livact } 2}=$ Slop of livelihood activity 2 contribute to community livelihood

$\beta_{3 \text { Livact } 3}=$ Slop of livelihood activity 3 contribute to community livelihood

$\beta_{4 \text { Livact } 4}=$ Slop of livelihood activity 4 contribute to community livelihood

$$
\mu=\text { Error term }
$$

A choice-based experiment was designed to analyses household state response toward an array of forest dependency. Household response relies on the assumption that they would select a community forestry dependency and indicate the level of important of each activities reflexed by their betteroff after establishment of CF.

Daily contribution of forest resources for community livelihood will be elicited based on stated response obtained from our questionnaire. The survey will develop to gather response base choice experiment from local household who are living in the forest and have strongly dependent on forest resource. The survey will collect information regarding individual's household activities toward forest resource and their personal opinion about how forest resource is important to their daily living. It will also gather demographic characteristics including age, gender, and household income that can be used as indicator in regression for comparison and investigate the change happening in different demographic characteristic.

\section{Econometric}

Responses to the household response, two differents model will be used to analyse the outcome.

Model 1 aimed to explain the impacts of forest dependency attributes only on stated choice response, the results of which will apply to investigate potential livelihood shares for forest dependency and other 
livelihood activities such as agriculture, fishing, home business ect.

Model 2 controlled for demographic characteristics (age, gender, year stay and income level), attitudes toward the use of forest resource. It will be developed to measure their interaction effects with different types of forest dependency attributes. Age will measure as a binary variable. Respondents older than the sample median were coded with a ' 1 ' and ' 0 ' otherwise (Suits, 1984). Gender will control for as a binary variable with female respondents coded as a ' 1 '. Attitudes toward the use of four type of forest dependency (NTFPS, livestock, rice farming, crop plantation, ect..) will be recoded with a ' 1 ' when there was agreement or strong agreement with the statement regarding to their choice response base on their daily activities. Those who response "no to (NTFPS, livestock, rice farming, crop plantation, ect..)" will be recorded as '0' otherwise.

\section{LITERATURE REVIEW}

\subsection{Community Forestry Development in Cambodia}

CFs' main objective is managing permanent forest estates in a sustainable way. The Royal Government of Cambodia (RGC) has choses a solution to the country's forestry crisis by turning Community Forestry into practice all over the countries. By 2006, it reached to 237 Community Forestry sites (Stephen R., 2006) ${ }^{17}$. Latter report from (FAO, 2011), there are 377 community forestrys with 347740 ha established in which, there are 13 potential areas with 20203 ha to be established ${ }^{18}$. Cambodia had first put Community Forestry into practiced in the mid-1990s via small pilot sites. In early 2011, almost 450 sites had been established which covered nearly 400,000 hectares by the beginning (FA, 2011) ${ }^{19}$.

Community Forestry (CF) in Cambodia has received considerable attention and has been regarded amongst donors as one viable concept to improve livelihoods of the rural population in order to prevent further environmental problems especially forest degradation and deforestation as well main tool for poverty reduction. As mentioned above, there are many CF sites has been established. However, (FAO, 2010) only 128 sites (covering 145500 hectares) have been officially approved by the Ministry of

17

Stephen R., 2006, Communities, Livelihoods and

Natural Resources: Action Research and Policy Change in Asia, IDRC, 01-Jan-2006- Business \& Economics pg.420

${ }^{18}$ Food and Agriculture Organization, 2011, FAO

Representation in Cambodia, March 2011

${ }^{19}$ Cambodia Forestry Administration, 2011
Agriculture, Forestry and Fisheries (MAFF) and Community Forestry agreements have been prepared for only 94 sites (covering 113500 hectares) $)^{20}$.

Improvement and development of community forestry in Cambodia have started from 1990 that still need more improvement of policies, law, implementation and monitoring (Seng H., Iida Sh, $2002)^{21}$. From the study of (Seng H. and Iida Sh, 2002), Problem among stakeholder maybe one of the factors that need to be cleared regrading to their role and responsivities. While there remain opportunities to grant local people control of forests, only degraded areas with little timber value have been allocated to Community Forestry.

A total of 3.6 \% of Cambodia's population and 3.1\% of it's villages are affected by $\mathrm{CF}$ activities (Fichtenau, et al., 2002) ${ }^{22}$. From this accounting, it is not a high potential of Community Forestry implementation comparing to neighbouring countries. The reason for less practice of CF in Cambodia is financial support for development of $\mathrm{CF}$ mainly supported by donor like NGOs and not much from the government.

From many studies, there is a general assumption that Community Forestry can contribute to biodiversity conservation and livelihood improvement. However, there have been proved by evidence from many studies of successful Community Forestry implementation that has effectively and efficiently contributed to improved nature conservation (biodiversity) and enhanced livelihoods is scarce as example of current practice in Nepal and some African countries. However, Community Forestry is becoming increasingly implement in Cambodia forest management sectors.

Indeed, Community Forestry contributes to the biodiversity while also contributing to livelihood improvement. On the other hand, this is still remaining as an uncertain question about effectiveness of community forestrymanagement in

\footnotetext{
${ }^{20}$ Food and Agriculture Organization, 2010, Growing green assets: Removing constraints to private sector investment in forestry in Asia and the Pacific, RAP PUBLICATION 2010/18.

${ }^{21}$ Seng H., Iida Sh, 2002, Community Forestry in Northern Cambodia, Formation Process and Regulation, pg.22-26, Pub No 50. 2002.03.

${ }^{22}$ Fichtenau, et al., 2002, An assessment of ongoing Community Forestry Initiatives in Cambodia, Department of Forestry and Wildlife, Phnom Penh, Cambodia
} 
Cambodia. Due to current situation, degradation of forest and the poverty level of local people in Cambodia are still remain worse among the other counties around the world.

\subsection{Socioeconomic Status of Rural Communities}

Although Cambodia is a country with rich of natural resources, decades of war and internal conflict leaving the country to be one of the world's poorest countries. $90 \%$ per cent Cambodia's poor people are in rural areas most of whom depend on agriculture for their livelihood. Small-scale farmers practice agriculture at the subsistence level, using traditional methods which giving low productivity.

Two thirds of the country's 1.6 million rural households face seasonal food shortages each year. Rice alone accounts for as much as 30 per cent of household expenditures (IFAD, 2007) ${ }^{23}$. Rural people are constantly looking for work or other incomegenerating activities, which are mainly temporary and poorly paid resulting some of them seeking job in the city or even other neighbour countries.

Generally, $80 \%$ of the Cambodian population live in rural areas and huge majority of these people are depending on agriculture that mostly refer to rice cultivation depending on natural feed rain. However, forest is one of a main source of dietary need (Equivalent to 17,000 US\$/community (MRC, $2014)^{24}$ ) such as food, fibre (vegetables) and protein; energy and wood sources especially for the poor. Depending on MRC, 2014 had mentioned in second Climate Change Forum that annual harvesting requirement: timber $94 \mathrm{~m} 3$, firewood $315 \mathrm{~m} 3$ and 700 poles for a community. A large number of cattle graze in forest (around 1,000/community). As the result, Rice+ Forest products could sustain the livelihood of the poor in the rural area.

From these inter-relation, some studies have shown that poverty has direct two-ways relations to forest (more poverty $=$ more dependency on forests + more exploitation and deforestation risk) Higher demand for timber, poles and energy for increasing populations brings pressure to forest Raw materials for construction - mining for sand, gravel and

23 International Fund for Agriculture Development, 2007, Rural Poverty in Cambodia, Enabling the rural poor to overcome poverty in Cambodia.

24 Mekong River Commission, 2014, Sustainable Forest Management for Climate Change Adaptation of Rural Vulnerable, Siem Reap, Cambodia laterite $^{25}$. Income generated from surplus products (evidence: thinning (creating gaps between trees) provided 500\$/ha in a Community forestryin Siem Reap) and forest carbon trade (REDD+) can be used to buy goods and services to increase adaptation capacity - such as health services, fans, nets and so on (APFC, 2012) ${ }^{26}$.

Cambodia's forest subsector contributed $8.4 \%$ to agricultural GDP over the period from 1999 to $2008^{27}$. This is an indication of the importance of forest resources for people living in rural area especially those who are living with direct dependent on forest resources. Annual income from forest varying from $12 \%$ to $34 \%$ of total income per household ${ }^{28}$. Seasonal agricultural crop mostly could not provide enough food throughout the year. Moreover, the decline in agricultural productivities causes more poverty to local people. In order to improve their livelihood, people living in the communities usually depend much on forest by increasing their activities for collecting various products from forests and nearby. Activities of local people for collecting various products occur differently throughout the year. Forests are also important for local livelihood in Cambodia (Seak, S. et al,. 2013 ${ }^{29}$. and Motzke I., et al, 2012 $2^{30}$. In addition to providing services, forests are important sources of food, medicine, construction material, and

${ }^{25}$ FAO, APFNet, Asian Forest Network, 2012, Assessment of the contribution of forestry to poverty alleviation in Asia and the Pacific, Making Forestry Work for the Poor, pg. 49-77. RAP Publication 2012/06

26 Asian-Pacific Forestry Commission, 2012, Growing Green Assets: Removing Constraints to Private Sector Investment in Forestry in Asia and the Pacific, pg1-27, 67-85, RAP Publication, 2010/18

27 Theng and Koy, 2011, Review of Agricultural Policy and Policy Research, CDRI

${ }^{28}$ Ra, K. and Sasaki, N., 2013, Assessment of Local Livelihood of Forest-Dependent Communities in Cambodia, International Journal of Environmental and Rural Development (2013) 4-1

29 Seak, S. et al,. 2013, Importance of Forest Ecosystem Services for the Livelihoods of a Rural Community in $O^{\prime}$ Som Commune, Pursat Province, Cambodia, Research Papers Vol. 1 (2012), ResearchGate

30 Motzke I., et al, 2012, Socioeconomic Context of Forest Biodiversity Use Along a Town Forest Gradient in Cambodia, National University of Singapore No. 25: 37-53, 30 Jun.2012 
firewood for household consumptions and income generation in Cambodia.

From (Ra, K. and Sasaki, N., 2013, and (Neang, $2009^{31}$ ) have suggested that collection of forest products varied seasonally in the community forestryecosystem which are driven by time availability of household and natural resource condition. This is showing that variation of local people behavior on forest resource use is depend on season and food availability from agriculture activities and also season for harvesting forest products. The interrelation of agriculture and forest resources are very essential to local community livelihood.

\subsection{Challenge among Community Forestry}

\subsubsection{Community Forestry and Food Security}

The September 2010 GIEWS Report confirms that improvements in food security have been satisfactory. However, climate change and high market volatility for agricultural products require sustained support to maintain Cambodia's successful development towards higher food security levels. Although Cambodia has recently experienced reductions in poverty rates and progress in economic growth, poverty and food insecurity are still prevalent in the country, especially in the rural areas.

In Cambodia, the rural people are dominant and the majority of the rural populations are farmers of which 75 percent depend on access to natural forest resources for essential products, energy and food $(\text { FAO, 2011) })^{32}$. Forests also provide supplementary income and employment. In Cambodia, one of the poorest countries in the world, 40 per cent of its 15 million people live on less than US\$1.25 a day. Yet an even higher poverty rate of 53 per cent is recorded in the northeastern provinces of Cambodia, home to many indigenous people. Traditionally, the indigenous people have close ties to the land and forest. They rely partly on forest resources for their livelihood. When they are short of food, they go to the forest and collect wild fruit and vegetables; sometimes they collect liquid resin to sell for money. At the same time, their way of living and their religion, which respects nature, allow them to keep the forest from being over-exploited.

31 Neang, T. (2009) Liquid resin tapping by local people in Phnom Samkos Wildlife Sanctuary, Cambodia. Cambodian Journal of Natural History2009(1): 16-25.

${ }^{32}$ Food and Agriculture Organization, March 2011
The indigenous communities have traditionally managed their land and forest communally, with each village having a clearly defined territory to which only people in that village have access, which is endorsed by law as well. Yet despite the law, more and more logging concessions have been granted to the business sector, and illegal loggers have been felling trees in the area in recent years. The logging seriously impacts the indigenous people's livelihoods and their way of life.

For poor farmers in rural Cambodia, food insecurity is high (Cheam, P. V., 2009) ${ }^{33}$. To increase their food security, farmers need to adapt well by growing alternate crops, raising chickens and pigs, digging and maintaining fishing ponds, and develop integrating agricultural method. As the agriculture cannot support their livelihood for whole year, subsistence from forest ecosystem in their community is very important (FAO, 1998). This is a clear example that more or less people use forest, it still become one of the primary source for rural community living close to forest. In short, for the rural poor, income from their agriculture products is rarely enough to sustain their families. Forest need to be carefully manage to extract its resources efficiently.

\subsubsection{Effectiveness of Community Forestry Management}

$\mathrm{CF}$ has been increasingly considered by the Cambodia government, NGOs, private sector agencies, and research scientists. The relevant sectors believed that $\mathrm{CF}$ should be pursued to manage the remaining forests. With the existing Sub-Decree on $\mathrm{CF}$, remaining forests are hoped to improve and maybe increase in the short future. Because of their wood and NTFP needs, local people will make sure that their CF resources are continuously available for them and future generations.

In Cambodia, there is a large population of rural poor, continued forest degradation and depletion of natural resources. As the result, poverty alleviation was included in the Cambodian National Strategic Development Plan (2006). Wide variety of community based programs are now implemented by RGC with strong support and cooperation with NGOs working towards increasing household income from natural Resources and promoting sustainable resource management. However, (Glen M. and Manuel B.,

33 Cheam P. V., 2009, NGO's Approach to Community Development in Rural Cambodia, CICP, No 30, 2009. 
2014) have argued that there is little success from this effort $^{34}$.

One of the purpose of establishment Community Forestry in Cambodia to secure access to land and forest resources for local communities, as well as seeking for sustainable forest use. Cambodia it is suggested that Community Forestry lack significant promise as a tool for poverty reduction only degraded forest with minimal economic potential has been granted for Community Forestry (Sundderlin, 2006 ${ }^{35}$ and McKenney et al., 2004 ${ }^{36}$ ). However, (Sarah M., and Sango M., 2015 and CDRI, 2014) had found that Community Forestry seems to better protect than direct management by government ${ }^{37}$.

In term of economic profit, utilization of Community Forestry in Cambodia have not yet been maximized. Communities close to markets lacked the raw materials to produce commercial products as the forests were already severely degraded (Glen M. and Manuel B., 2014) ${ }^{38}$. Forest dependency among rural community for forest use or traditional farming systems remains high; they have few or no alternative sources of income (CDRI, 2014) ${ }^{39}$. Interaction between management type, CF or control, and forest dependence indicated that $\mathrm{CF}$ was more effective in cases where the community relied on forest products for subsistence use and income (Frances H. L., et al, $2014)^{40}$.

34 Glen M. and Manuel B., 2014, No forest, no NTFPs for rural communities in Cambodia, No. 67, February 2014 cifor.org

35 Sunderlin, W. D., et al, 2006. Livelihoods, forests, and conservation in developing countries: An overview. World Development, 33: 1383-1402.

36 McKenney, B. et al, 2004, Focusing on Cambodia's high value forests: Livelihoods and management. Phnom Penh

37 Sarah M. and Sango M., 2015, Conservation and Development in Cambodia: Exploring Frontiers of Change in Nature, State and Society, Business and Economic, pg. 310.

38 Glen M. and Manuel B., 2014, No forest, no NTFPs for rural communities in Cambodia, No. 67, February 2014 cifor.org

39 Lonn P. et al., 2014, Community Forestry for Sustainable Forest Management and Livelihoods: Cambodia Development Review, CDRI, Vol 13, Iss 3, September 2014

${ }^{40}$ Frances H. L., et al, 2014, Effectiveness of Community Forestry in Prey Long Forest, Cambodia, Conservation Biology Volume 00, No. 0, 2014
From all of these studies, we can conclude that means in $\mathrm{CF}$ practice would greatly enhance our understanding but the variation in the effectiveness of $\mathrm{CF}$ is upon real situation of practice itself. In Nepal where highly recognized as one of the best practice in Community Forestry management which very effective in term of economic improvement while forest ecosystem is degrading (Nagendra H., 2002) ${ }^{41}$. Likewise, CFs in Myanmar have been resulting remarkable improve of livelihood especially income but sign of forest degradation also appear to be a great challenge (Phyo Th., 2014) ${ }^{42}$. The same story happened in India (Rossi F. J., 2007 ${ }^{43}$ ) and Sri Lanka (De Zoysa M., and Inoue M., 2008 ${ }^{44}$ ). From these research's finding, CFs are highly effective in term of socioeconomic improvement but certain about forest ecosystem status is still under questioning for several reason.

${ }^{41}$ Nagendra H., 2002, Tenure and forest conditions: community forestry in the Nepal Terai, Environmental Conservation 29 (4): 530-539, Foundation for Environmental Conservation, 2002

${ }^{42}$ Phyo Th., 2014, Impact of Community Forestry on Local Livelihood: Case study in dry zone, Myanmar, Department of Forest Science, Seoul National University.

43 Rossi F. J., 2007, Socioeconomic Impacts of Community Forest Management in Rural India, University of Florida, 2007

44 De Zoysa M., and Inoue M., 2008, Forest Governance and Community Based Forest Management in Sri Lanka: Past, Present and Future Perspectives, International Journal of Social Forestry (IJSF), 2008, 1(1):27-49, www.ijsf.org. 


\section{RESULTS}

Table 2: Logistic regression result of variable that have the p-value $<0.05$ which are statistically significant

\begin{tabular}{|c|c|c|c|}
\hline \multicolumn{4}{|l|}{ Variable } \\
\hline First Important Attribute & $\beta$ & OR & P-Value \\
\hline Fishing & -.2943384 & .7450243 & 0.031 \\
\hline Rice Farming & -1.888728 & .1512642 & 0.024 \\
\hline Crop Plantation & -1.601045 & .2016855 & 0.021 \\
\hline \multicolumn{4}{|l|}{ Second Important Attribute } \\
\hline Rice Farming & -.5919352 & .5532556 & 0.024 \\
\hline Livestock & -.7717471 & .4622048 & 0.039 \\
\hline Home Business & -.3042531 & .376741 & 0.045 \\
\hline \multicolumn{4}{|l|}{ External Factors Attribute } \\
\hline Owning Land Area & -.0000441 & 9999559 & 0.010 \\
\hline Years Stay & .1863443 & .204837 & 0.043 \\
\hline \multicolumn{4}{|l|}{ Fishing Attribute } \\
\hline Crab Fishing & .3856625 & .470588 & 0.035 \\
\hline Gillnet Fishing & .6539265 & .23077 & 0.039 \\
\hline Fishing & .5798185 & .385714 & 0.028 \\
\hline \multicolumn{4}{|l|}{ Government Attribute } \\
\hline Forestry Commune Council & -.5543157 & .5744652 & 0.044 \\
\hline Department Environment & -2.300559 & .0886708 & 0.031 \\
\hline NGOs & .170946 & .186427 & 0.043 \\
\hline \multicolumn{4}{|l|}{ Resource Decline Attribute } \\
\hline Fish Diversity Decline & 1.895173 & .653702 & 0.015 \\
\hline Catch Decrease & 1.512772 & .539298 & 0.037 \\
\hline \multicolumn{4}{|l|}{ Cause of Decline } \\
\hline Tide & .1232713 & .131191 & 0.027 \\
\hline Rain & -1.091036 & .3358682 & 0.014 \\
\hline
\end{tabular}

\subsection{Livelihood Activities}

This section of the survey defines what each household's main livelihood activities are currently considered to be the most important livelihood activities. Having respondents evaluating their priority livelihood activities can indicate the respondent's perception on their reflection of community forestry contribution to their daily living in which the household depends on for their livelihood. The most important livelihood activities that is sharing in the better off after establishment of CF was fishing activities which is contributed $74.5 \%$ following by crop plantation and rice farming $20.16 \%$ and $15.12 \%$ respectively. The second livelihood activities that expected from villagers in
Toul Kaki was home rice farming $55.32 \%$ following by livestock and home business $46.22 \%$ and $37.67 \%$ respectively. External factors that are statistically significant to better off are those villagers who owned large area of land and have been spending long time staying in the village.

\subsection{Fishery Contribution to Livelihood}

This section shows the different ways of fishing activities that households may observe as their important factor for their families. Among all attributes, crab fishing that $47 \%$ that had the highest odd ratio sharing the local livelihood prosperity. The other fishing activities were gillnet fishing $23 \%$ and marine fishing $38.57 \%$. 
5.3. Challenges for Local People in Toul Kaki Commune

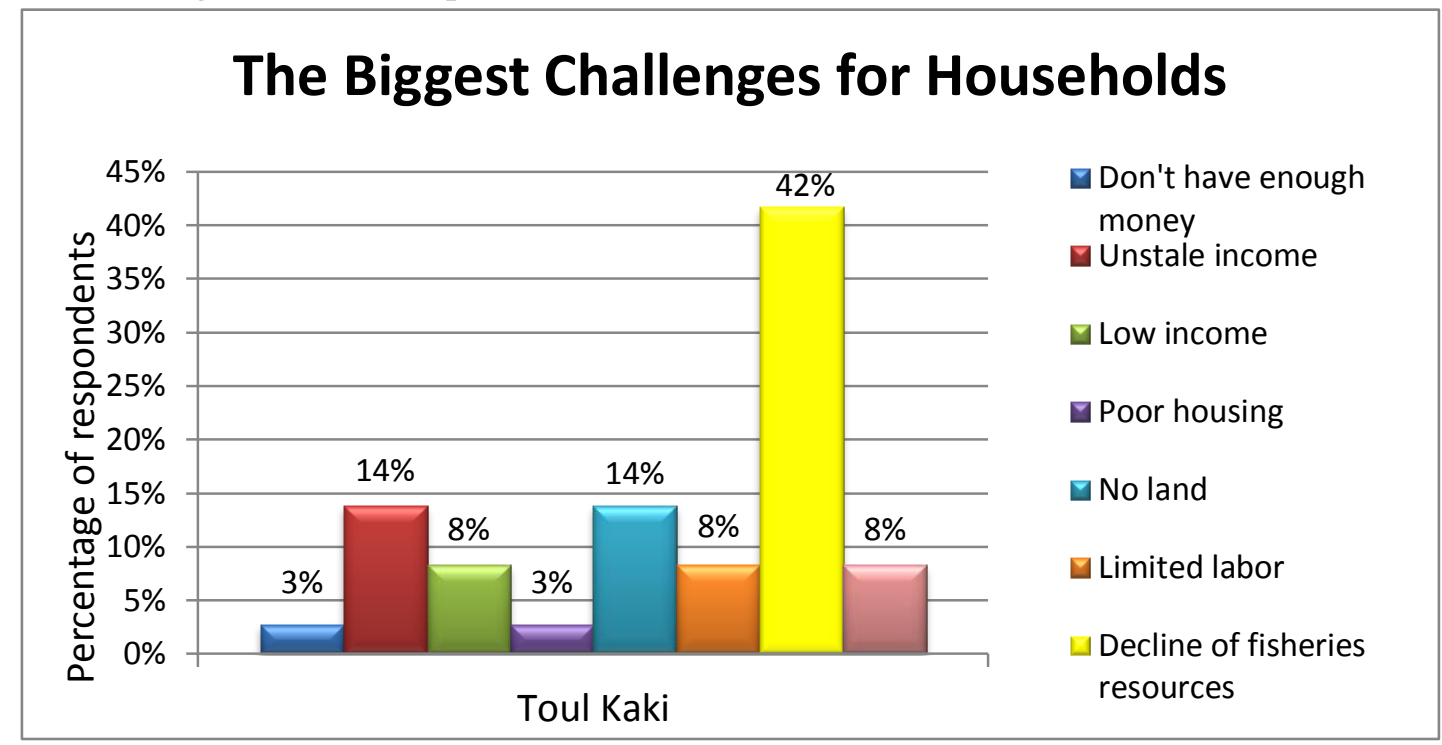

Figure 5: Challenge concerning by local people for currently situation in the commune.

As we can see in the chart above, up to $42 \%$ of the total respondents said that decline of fisheries resources was the biggest challenge for households in Toul KaKi Commune. Only 14\% of those villagers agreed that no land is the biggest challenge for their families. From table 1, those resource declines were causing by climate change including changing tide level $13.11 \%$ and too much rain up to $33.5 \%$.

\subsection{Perception of Resource Change}

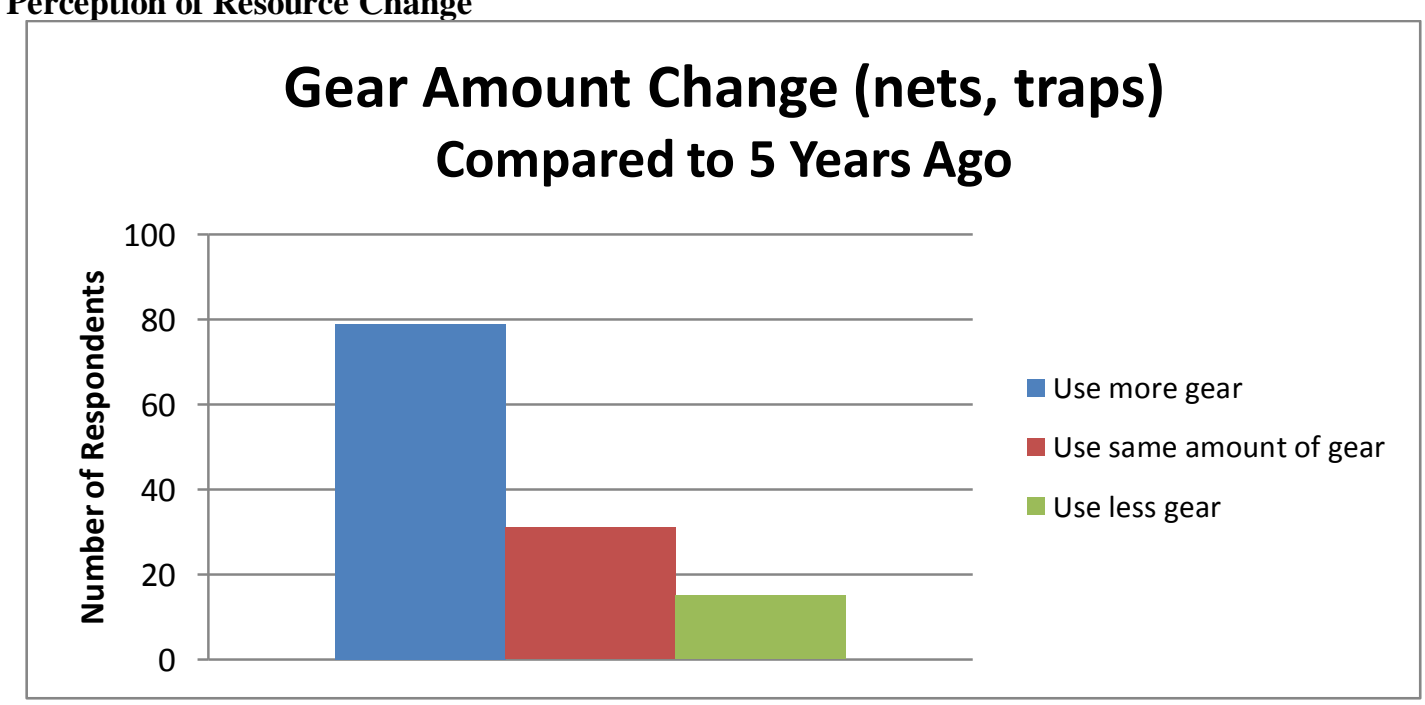

Perceptions of change in species size, diversity, and total catch are represented by village. To maintain their livelihood, local households changed their methods of catching fish in the past 5 years; including different mesh size, and/or the amount of gear being used. Up to $66.67 \%$ of target households noted that they used more fishing gear following the chart above. On the other hand, $33.33 \%$ of respondents agreed that they used the same fishing gear over the past five years. Fishery declines made high number of diversity decline in the past 5 year (table 1). Fishing catch also affect the livelihood up to $53 \%$ (table 1$)$.

\subsection{Interventions from Government Institutions and Others}

For improvement of institutional factors, people's perception of the roles and implementations of various institutions including village management committee, community-level organizations, and provincial government agencies, is important to take into account for capacity building within their community. While asking about which institution 
was most involved in their livelihood activities, almost all households agreed that forestry commune council was most involved in their livelihood activities following by local NGOs and department of environment (table 1).

\section{DISCUSSION}

In term of food accessibility, they could have access to food through their main livelihood activities that make their family better off after the establishment of community forestry. The main livelihood activities that contribute to their family in Toul Kaki Commune were NTFP activities which refer to fishing in this CF that consist many types of fishing in the mangrove forest. The most fishing activity is crab fishing which is important to the local livelihood in Toul Kaki as same as the whole coastal area. Crab eating is very popular in the area where a lot of people come to relax as the area in one of the tourist attraction site. Crop planation and rice farming which is the traditional livelihood activities are the second most important to them. Other livelihood activities observed including raising animals, and other activities. This community relies on a mixture of livelihood activities that are related to fishing, agriculture, and other services. In addition, still these occupations will be the main occupations for the alternative.

In term of environmental changes, people in Toul Kaki observed that resource declines were causing by climate change including changing tide and raining level. These environmental changes impact to the livelihood of people living in Toul Kaki Commune so much. On the other hand, decline of fishery resources caused moderate impact on local livelihood since they generally go fishing to support their families in term of food and income from mangrove forest resources. From these impact, local villager whose main occupation is fishing have observed change of aquatic species size, change of aquatic species diversity and change of total catch over the past 5 years in term of fishery resources. This indicates that the NTFP resource in mangrove forest has been decreased. To tackle the problem, most of the target households have used more fishing gear to maintain their catch amount. However, they have not changed the mesh size.

Although we have Department of Climate Change and other policies and strategic objectives regarding climate change adaptation, people in Toul Kaki Commune did not get any good support in term of resilience to climate change from Department of Climate Change since this department lacked of fund for adaptation activities supporting local livelihood. Also, Cambodia has just lately adopted Department of Climate Change. On the other hand, forestry commune and the local NGOs have the main support to the whole community.

\section{CONCLUSION}

In conclusion, as the community forestry in Toul Kaki is more rely on rice farming and fishery resource, this community forestry has a great different from other community forestry. Fish resources are the main contribution from forest as the main NTFPs in the community. However, the community forestry has been successfully implemented. From livelihood reflection, most of local people living in Toul Kaki said that their livelihood has been better compared to 5 years after the establishment of CF. However; institutional factor should be taken into account for the improvement of $\mathrm{CF}$ practice. As fishery resources are the main source for local people in Toul Kaki, their big challenge is fishery resources decline that account up to $42 \%$ of their overall concern following by land resources and unstable income. Related institute like Climate Change Department should have more attention on their reflection on climate change that has impact on local livelihood activities. On the other hand, forestry commune council was the most active institute helping and support local community for their livelihood activities with the help of local NGOs that were doing relevant activities.

\section{References:}

1. Alexandra B, Christian S, David H. G and Koy R. 2014 Forest Land Conversion and Conversion Timber Estimates, Cambodia Case Study, NEPCon as commissioned by Forest Trends.

2. Azhar B., David B. L., Wood J., Fischer J., Zakaria, M. 2014, Ecological impacts of oil palm agriculture on forest mammals in plantation estates and smallholdings, Biodiversity and Conservation, May 2014, Volume 23, Issue 5, pp 1175-1191

3. Biddulph, R. 2010. Geographies of evasion: the development industry and property rights interventions in early 21 st century Cambodia. University of Goethenburg, Departments of Geography Series B, No. 117.

4. Blomley, T., T. Prom, K. Mam, D. Eam, and M. Dubois. 2010. Review of Community Forestry and community fisheries in Cambodia. Report prepared for the Natural Resource Management

5. Brian W., and Gray S., 2006. Species richness and evenness respond in a different manner to propagule density in developing prairie microcosm communities, Springer Science and Business Media B.V. 2006

6. Braeutiga D.,2003, Community Based Forest Management in Cambodia and Laos, MRC-GTZ Cooperation Programme, Phnom Penh, October 2003, Working Paper 3

7. Dodds K., 2002. Freshwater Ecology: Concepts and Environmental Applications, Academic Press, San Diego, California, USA, 2002

8. Camille B. 1997., An Economic Analysis of Tropical Forest Land Use Option, Ratanakiri Province, Cambodia, Economy and Environment Program for Southeast Asia, Singapore 912404 
9. CDRI, 2014, Cambodia Development Review, Community Forestry for Sustainable Forest Management and Livelihoods, Volume 18, Issue 3.

10. Chanthou H., 2014, Assessing Community Based Natural Resources Management Effectiveness in Siem Reap Province, Department of Research Forum, April 2014, No.04

11. Cheam P. V., 2009, NGO's Approach to Community Development in Rural Cambodia, CICP, No 30, 2009.

12. De Lopez T. T., 2000, Resource Degradation, Property Rights, Social Capital and Community Forestry in Cambodia, Cambodian Research Centre for Development (CRCD), Kingdom of Cambodia.

13. De Zoysa M., and Inoue M., 2008, Forest Governance and Community Based Forest Management in Sri Lanka: Past, Present and Future Perspectives, International Journal of Social Forestry (IJSF), 2008, 1(1):27-49, www.ijsf.org.

14. Elliott V. et al, 2010, Biodiversity Surveys in the Community forestrys of Oddar Meanchey, Cambodia, Birdlife International, January 2011

15. Fichtenau J. et al., 2002, An Assessment of ongoing Community Forestry Initiatives in Cambodia-Implications for the Development of a Forestry Extension Strategy, Department of Forestry and Wildlife, Phnom Penh, 2002.

16. Food and Agriculture Organization, (na year), Forestry Department, National Forest Products Statistics, Cambodia

17. Food and Agriculture Organization, 2010, Growing green assets: Removing constraints to private sector investment in forestry in Asia and the Pacific, RAP PUBLICATION 2010/18

18. Fox J., Vogler J. B., Poffenberger M., 2009, Understanding Changes in Land and Forest Resource Management Systems: Ratanakiri, Cambodia, Southeast Asian Studies, Vol. 47, No. 3, December 2009

19. Frederick C. Et al, 2013, Financial and Economic Evaluation Guidelines for Community Forestry Projects in Latin America, Program on Forests (PROFOR)

20. Glen M. and Manuel B., 2014, Glen M. and Manuel B., 2014, No forest, no NTFPs for rural communities in Cambodia, No. 67, February 2014 cifor.org

21. Hostetler, M.E. 2002. Bird Monitoring Projects for Youth: Leader's Guide. University of Florida Cooperative Extension Service Fact Sheet WEC 159. 6 pp. University of Florida, UF/IFAS EDIS Database, http://edis.ifas.ufl.edu/UW165.

22. Hugh L. W., 2012, Resource use and livelihood change in Cambodia's dry forests: implications for conservation, BirdLife International, December 2012

23. International Fund for Agriculture Development, 2007, Rural Poverty in Cambodia, Enabling the rural poor to overcome poverty in Cambodia.

24. James J. H. and Rick L. T., 2013, Forest Degradation in Cambodia: An Assessment of Monitory Options in the Central Cardamom Protected Forest, United States Forest Service, February 2013

25. K.C., Birendra, "SOCIO-ECONOMIC STUDY OF COMMUNITY FORESTRYS IN MID HILLS REGION OF NEPAL" (2012)

26. Kao and Iida (nnn), Structural characteristics of logged evergreen forests in Preah Vihear, Cambodia, 3 years after logging, Faculty of Agriculture, Kyushu University 394, Tsubakuro, Sasaguri-Machi, Fukuoka 811-2415, Japan

27. Keshav R. K and Ganga R. D, 2008, COMMUNITY FORESTRY POLICY AND ITS ECONOMIC IMPLICATIONS: AN EXPERIENCE FROM NEPAL, International Journal of Social Forestry, 2008, 1(1):50-60. ISSN 1979-2611

28. Kimsun T., at al., 2013, Levels and Sources of Household Income in Rural Cambodia 2012CDRI, August 2013, Working Paper Series No. 83

29. Koy R. and Tong K., 2012, Financial viability of plantations of fast-growing tree species in Cambodia
30. Kristen E. and Manuel R. G. 2008, Review of Tool, Concept and Lesson Learn of Participatory Monitoring in Tropical Forest Management,

31. Larindel, S.L. AND O. Olasupoo, 2011, SOCIOECONOMIC IMPORTANCE OF FUELWOOD PRODUCTION IN GAMBARI FOREST RESERVE AREA, OYO STATE, NIGERIA, Forestry Research Institute of Nigeria, Ibadan, Nigeria

32. Main , M. B., Hostetler, M. E., and A. Karim. 2003. Evaluating Private Lands for Conservation of Wildlife. University of Florida Cooperative Extension Service Fact Sheet WEC 164. 2 pp. University of Florida, UF/IFAS EDIS Database, http://edis.ifas.ufl.edu/UW195

33. Mekong River Commission, 2014, Sustainable Forest Management for Climate Change Adaptation of Rural Vulnerable, Siem Reap, Cambodia

34. McKenney B., Et al, 2004, Focusing on Cambodia's High Value Forests: Livelihoods and Management, CDRI and Wildlife Conservation Society, Cambodia.

35. Motzke I., et al, 2012, Socioeconomic Context of Forest Biodiversity Use Along a Town Forest Gradient in Cambodia, National University of Singapore No. 25: 37 53, 30 Jun. 2012

36. Nagendra H., 2002, Tenure and forest conditions: Community Forestry in the Nepal Terai, Environmental Conservation 29 (4): 530-539, Foundation for Environmental Conservation, 2002

37. Nang P., et al, 2011, Sustainable Agriculture and Environmental Protection in the Tonle Sap Plain: Improving IWRM and Farmer Practices, CDRI, Volume 15 , Issue 3 .

38. National Institute of Statistics, 2013, Cambodia Socioeconomic Survey,Ministry of Planning, Phnom Penh, July 2014

39. Phal B. et al, 2000, Touk Kaki Community forestry, Siem Reap Province, MRC/GTZ, May 2002

40. Phyo Th., 2014, Impact of Community Forestry on Local Livelihood: Case study in dry zone, Myanmar, Department of Forest Science, Seoul National University.

41. Pichdara L. et al., 2014, COMMUNITY FORESTRY FOR SUSTAINABLE FOREST MANAGEMENT AND LIVELIHOODS: A CASE STUDY OF OSOAM COMMUNITY FORESTRYUSERS GROUP, Cambodia Development Review, CDRI, Vol 13, Iss 3, September 2014

42. Ra, K., Pichdara, L., Dararath, Y., Jiao, X., \& Smith-Hall, C. (2011). Towards understanding household-level forest reliance in Cambodia - study sites, methods, and preliminary findings. Forest \& Landscape, University of Copenhagen.

43. Rossi F. J., 2007, Socioeconomic Impacts of Community forestryManagement in Rural India, University of Florida, 2007

44. Sarah Milne, Sango Mahanty, 11-Feb-2015 - BUSINESS \& ECONOMICS - 310 pagesConservation and Development in Cambodia: Exploring Frontiers of Change in Nature, State and Society

45. Sayer J., 2005, An ITTO mission to Cambodia recommends the cautious resumption of timber-harvesting, ITTO Tropical Forest Update 15/1, 2005

46. Seng H., Iida Sh., 2002, Community Forestry in Northern Cambodia, No. 55, 2002

47. Socheat L. S., (unknow year), Indicating Success: Evaluation of Community Protected Areas in Cambodia, Department of Nature Conservation-Protection, Ministry of Environment Phnom Penh, Cambodia

48. Stephen R., 2006, Communities, Livelihoods and Natural Resources: Action Research and Policy Change in Asia, IDRC, 01-Jan-2006 - Business \& Economics pg.420

49. Sunderlin, W. D., et al, 2006. Livelihoods, forests, and conservation in developing countries: An overview. World Development, 33: 1383-1402. 
50. Sunderlin, W. D., J. Hatcher, and M. Liddle. 2008. From exclusion to ownership. Challenges and opportunities in advancing forest tenure reform. Rights and Resources Initiative, Washington, D.C

51. Tola P. and Bruce Mc., 2003, Trading Forest Products in Cambodia: Challenges, Threats, and Opportunities for Resin, Cambodia Development Resource Institute Phnom Penh

52. Ty S., 2013. "Evaluation of Community Forestry in Cambodia." Presentation at Asia Forest Workshop, Phnom Penh, 3-4 Dec
53. Vittoria E., Et al., 2010, Biodiversity Assessment of the REDD Community forestryProject in Oddar Meanchey, Cambodia, Bird Life International and Pact Cambodia.

54. Yasmi, Y., L. Kelley, and T. Enters. Forest conflict in Asia and the role of collective action in its management. CAPRi Working Paper No.102. Washington, D.C. International Food Policy Research Institute. http://dx.doi.org/10.2499/CAPRiWP102

55. Yeang, D. (2012). Community Tenure Rights and REDD+: A Review of the Oddar Meanchey Community Forestry REDD+ Project in Cambodia. ASEAS - Austrian Journal of South-East Asian Studies, 5(2), 263-274. 